\title{
Development of Mathematics Learning Tools Through Geogebra-Aided Problem Based Learning To Improve Solving Capability Mathematical Problems of High School Students
}

\author{
Nurmillah Br Sembiring \\ Education of Mathematic \\ State University of Medan \\ Medan, Indonesia \\ nurmilkasemb@gmail.com
}

\author{
Asmin \\ Department of Mathematics \\ State University of Medan \\ Medan, Indonesia
}

\author{
Edy Surya \\ Department of Mathematics \\ State University of Medan \\ Medan, Indonesia
}

\begin{abstract}
This research is a study of the development of learning devices. This study aims to analyze how the validity, practicality and effectiveness of mathematics learning tools through Geogebra-assisted problem-based learning are developed and analyze how to improve students' mathematical problem-solving abilities after being taught using the developed learning tools. The products produced in this study are learning implementation plans, teacher books, student books, and student activity sheets. The development of this learning device uses a 4D development model developed by Thiagarajan, Semmel and Semmel which consists of four stages, namely, define, design, develop, and disseminate. This research was conducted in two trials in two different classes, namely class XI MS 1 and XI MS 2 in SMA 1 Kabanjahe. Data from the results of this study were analyzed descriptively. The results of the study show that: (1) learning devices developed meet all validity criteria, both content validity and construct validity; (2) learning devices developed meet all practicality criteria, seen from: a) validator assessment and b) implementation of learning devices; (3) learning devices developed meet all effectiveness criteria, viewed from: a) completeness of student learning outcomes, b) student activities, and c) student positive responses; (4) students' mathematical problem solving abilities increase using the learning tools developed. Increased students' mathematical problem solving abilities seen from the results of the post-test trial I and trial II.
\end{abstract}

Keywords-Development of Learning Device; Problem Based Learning; Problem Solving Ability; Geogebra.

\section{INTRODUCTION}

The world of education in Indonesia is currently faced with two major problems, namely the low quality of education and inadequate school learning systems. The low quality of education is indicated by the results of a survey of The Program for International Student Assessment (PISA) in 2009, mathematics learning achievement of students in Indonesia ranked 61 out of 65 countries that participated with the acquisition of a mean score of 371 , while the average international score was 500 ( Balitbang, 2011). The scores obtained are significantly below the international average score.

The conclusion from the survey results of The Program for International Student Assessment (PISA) in 2009, is not much different from the mathematical ability of students of SMA Negeri 1 Kabanjahe, where the average value of UNBK (Computer Based National Examination) mathematics at SMA Negeri 1 Kabanjahe students in the year 2017 is 43,565 and in category D. Of 320 students of class XII Natural Sciences and Social Sciences of SMA Negeri 1 Kabanjahe in the 2016/2017 school year there are 17 students or equal to $5.313 \%$ of students who complete in categories $\mathrm{A}, \mathrm{B}$ and $\mathrm{C}$ while students who have not yet completed as many as 303 students or equal to $94.668 \%$. In this case it appears that the mathematical ability of SMA Negeri 1 Kabanjahe students is still low. So it can be concluded that the mathematical problem solving ability of students of SMA Negeri 1 Kabanjahe is also still low.

The statement in the field shows that mathematics is still considered as a complex math lesson and too many formulas. This happens because the teacher in the learning process does not provide problem-based questions that can develop problem-solving abilities

The teacher is more focused in pursuing the achievement of completion of all subject matter. So that teachers are more accustomed to giving questions that can be done with a quick formula. In addition, abstract mathematical objects are also considered as factors that cause students to have difficulty in applying mathematical concepts to the everyday problems presented. In addition to the above problems, the writer also found other problems in the field.

The weakness of students in applying mathematics due to the low ability to solve mathematical problems of students. During the author's observations, the authors observed that students tend to be passive in following the process of learning mathematics in the classroom. Students tend to feel scared and anxious when expressing their opinions, even students are afraid to ask questions about things that are not understood. 
One learning model that can be used so that students are active in learning and is well used in developing contextual and open ended mathematics learning and Student-centered learning is a problem based learning model. According to Silver (2004: 235): "In PBL, student learning centers on a complex problem that does not have a single correct answer". Which means that in the problem based learning model, student-centered learning where a complete problem does not only have one correct answer.

Most students consider mathematics as a problem, so the Problem Based Learning (PBL) model is very suitable in learning mathematics. Problem based learning can be applied to mathematics learning to improve students' problem solving abilities. According to Sanjaya (2006: 214) "problem-based learning (problem based learning) is a series of learning activities that emphasize the process of solving problems faced scientifically".

Meanwhile, according to Tan (in Rusman, 2011: 232) argues that "problem-based learning (PBM) is the use of various kinds of intelligence needed to confront real world challenges, the ability to deal with new things and existing complexities".

Widyatiningtyas (2016: 370) also revealed in his journal that: "Problem-based learning should be developed in the field and can be used as an alternative option for the implementation of learning mathematics and making the suggested teaching materials in the form of more challenging for students and in order to exist trigger for cognitive conflict. In essence, the problem based learning model becomes one of the highly recommended models in learning mathematics which is challenging for students".

With problem-based learning (PBM), it is hoped that learning objectives can be achieved. Problem Based Learning (PBL) model is a student-centered learning model so that students can be active, creative, and innovative in solving real context problems or story problems so that the problem-based learning model (PBM) is expected to improve students' mathematical problem solving abilities .

The purpose of problem based learning is to assist students in developing: their knowledge, effective problem solving abilities, learning in their own direction, expertise in collaboration and can increase motivation.

Teachers as education implementers are required to have tools in implementing learning to maintain general goals and specific objectives so that the educational process runs in accordance with the expectations of the government. According to Subanindro (2012: 3) in simple language learning devices are defined a set of learning resources arranged in such a way that students and teachers carry out learning activities. learning tools have a very important role for a teacher in the learning process. The following are some of the reasons why learning tools are so important for a teacher, Rahmadani (2015: 6), among others: “(1) learning tools as a guide; learning tools are a guide for teachers in carrying out their duties in class. With the learning tools, the learning process will run according to the plan prepared by the teacher. (2) Learning tools as benchmarks; in the presence of a device learning, teachers can analyze the ability of students to the subject matter that has been presented. The teacher can see to what extent the material that has been presented is absorbed by students. How many students still need special guidance, and can be used as a reference in the next learning process. (3) Learning tools as professionalism enhancement; with the learning tools, teachers can increasingly hone their abilities in preparing learning implementation plans that can increase the professionalism of teachers at work. (4) Learning tools make it easier for teachers to help the learning facilitation process; with the learning tools, teachers can more easily make learning innovations that can interest students in the learning process".

In order for the learning process to achieve the expected learning objectives, it is necessary to develop learning tools that are appropriate to the model or approach applied. In developing learning tools, the preparation of learning tools should be able to facilitate students in understanding the material. A teacher who does not master the subject matter to be taught may not be able to teach well, likewise if the teacher cannot develop the right learning device on the material being taught, then learning does not provide optimal results.

Every teacher before starting the lesson must first prepare all learning tools before he teaches, be it RPP, teaching materials, and LAS, it is also possible to use media so that learning is more interesting and easily understood by students, and do not forget what learning strategies, methods, or models which will be applied later.

In developing quality learning tools there needs to be an assessment of the product being developed. To determine the quality of the results of the development of learning tools generally three criteria are needed: validity, practicality, and effectiveness. As expressed by Nieveen (1999: 126) "In order to make the concept" quality "more transparent, it was related to a topology of curriculum representations, resulting in a framework with three quality criteria: validity, practicality, and effectiveness".

Learning mathematics can be a fun experience for every student. This depends on the teacher in conveying mathematics as an interesting application Edge (in Afgani, 2008: 46). One strategy for teaching mathematics that can reach all students is to access the internet and use the mathematical software Furner, et al (in Afgani, 2008: 46).

Furthermore, for the implementation of learning that makes students active and more motivated in learning mathematics, media or technology is needed so that there is time for students to think. Utilization of computer technology in which there is software such as GeoGebra in mathematics learning is one way of providing opportunities for students to more actively develop their mathematical problem solving abilities.

Various benefits of computer programs in mathematics learning are stated by Kusumah (2003: 1). According to him, computer programs are ideal to be used in learning mathematical concepts that require high accuracy, repetitive concepts or principles, completing graphics accurately, quickly, and accurately. Furthermore Kusumah (2003: 1) also 
suggested that learning innovations with the help of computers are very good to be integrated in learning mathematical concepts especially those involving geometry, calculus, statistics and graphs of functions.

One computer program that can be used as a medium for learning mathematics is GeoGebra. With a variety of facilities, GeoGebra can be used as a medium of mathematics learning to demonstrate or visualize mathematical concepts as well as tools to construct mathematical concepts. GeoGebra is a free learning software based on mathematics developed by Markus Hohenwarter from Austria. Tran (2014: 44) states that: "This software can allow teachers and students to find out solutions of geometric problems. It also can create a lot of new problems". Especially, the GeoGebra software is free. That's the reason why teachers and students should use the one. In addition, students will develop technology skills and get mathematical knowledge easily.

Thus GeoGebra, is one of the software that can help students and teachers in solving problems in learning mathematics for example in solving linear program problems so that they can be solved easily.

Based on the description above, researchers are interested in conducting a study entitled "Development of Mathematics Learning Tools Through Geogebra-Aided Problem-Based Learning to Improve the Mathematical Problem Solving Ability of High School Students."

\section{METHOD}

This research includes development research. In this research, a learning tool developed in the form of a teacher's book, student books, student activity sheets and tests of students' mathematical problem solving abilities. The development process is related to activities at each stage of development. The final product is evaluated based on the specified product quality aspects. Thus the product of this research is a mathematical learning tool through geogebraassisted problem-based learning to improve students' mathematical problem solving abilities that are valid, practical and effective. This research was conducted at SMA Negeri 1 Kabanjahe in the 2018/2019 school year on linear program material.

This research is divided into two stages, the first stage is the development of learning tools. Development of learning tools which include: (1) the validity of the Teacher's Book; (2) the validity of Student Books; (3) the validity of LAS; (4) the validity of the instrument tests students' mathematical problem solving abilities. The second stage is the implementation of learning tools that have been validated to see their practicality and effectiveness.

There are several learning system development models including: 1) PPSI Model (Instructional System Development Procedure); 2) The Dick and Carey Model; 3) Kemp model; 4) Model Thiagarajan, et al. But the development model that will be used to develop learning tools in this study is the
Thiagarajan et al model known as 4-D Models (4D Models) so that this model will be explained. The 4D model was chosen because it is systematic and suitable for developing learning tools and the development results obtained have been revised based on the assessment of experts before being tested on students. Thiagarajan (1974) states that the learning tools developed have been rated by experts / experts through the validation stage.

The Thiagarajan, Semmel, and Semmel models, namely the 4-D Model, consist of four stages: define, design, develop and disseminate.

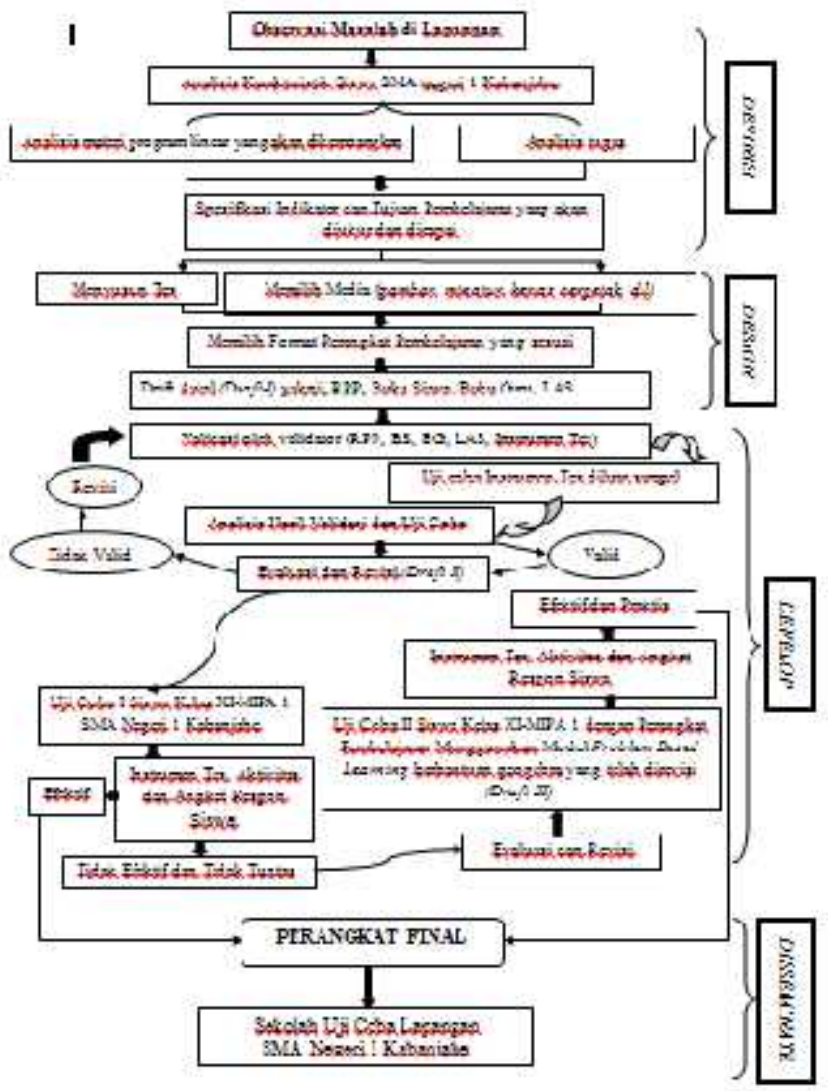

Fig.1. Chart for developing 4-D model learning tools (Trianto, 2011)

The trial design that will be used in the development of the instrument is One - group pretest - posttest design. As follows :

\begin{tabular}{|lcc|}
\hline Tes & treatment & Tes \\
$\mathrm{T}$ & $\mathrm{x}$ & \\
\hline
\end{tabular}

Information :

$\mathrm{T}_{1}=$ Pre-test

$\mathrm{T}_{2}=$ Post - test

$\mathrm{X}=$ Treatment of lessons based on contextual approaches. 


\section{RESULTS AND DISCUSSION}

The device developed was validated both in content and construct. The results showed that all validators gave an assessment that the device developed was valid based on an assessment of the writing format, language, content, and illustrations on the device developed. The evaluation of the validity of this tool is also in accordance with the aspects of assessment revealed by Syahputra and Surya (2017: 81) where aspects assessed in seeing validity are whether the student book and the teacher's book are in accordance with the steps of the scientific approach, whether the material meets the suitability of the order of the material, whether the sentence used is easy to understand, whether the sentence used in the book is unambiguous, whether the appearance and contents of the book are interesting, whether the question questions vary, whether the problem is a contextual problem, whether the sentence in the problem is unambiguous.

After the learning device developed is declared valid, then a trial is carried out on the learning device developed to see the practicality and effectiveness of the learning device. This trial was carried out twice. Based on the results of testing the learning device in the first trial phase, obtained information and research findings that form the basis for improving the learning device. This is because in the first trial phase, the implementation of learning has not yet reached the specified criteria so it does not meet practical criteria. After a revision and continued trial II, the results were obtained that the problem-based learning oriented learning tools that were developed met practical and effective criteria. Practicality is evaluated from the validators' evaluation and the implementation of the learning tools. While the effectiveness is seen from the completeness of classical learning outcomes of students, student activities, and positive responses of students to the learning activities and devices developed.

The findings of this study are in line with those proposed by Padmavathy and Mareesh (2013), namely "problem based instructional learning strategies have an effect on content knowledge which provides greater opportunities for learners to learn a content with more involvement and increase the students active participation, motivation and interest among the learners ". And research on the effectiveness of problem based learning models by Walker and Lofton (2003) obtained that "students' willingness to learn increase and their attitudes improve in a positive manner by using problem based learning model". This is in accordance with the criteria of practicality and effectiveness in the development of learning tools where by using the problem based learning model students' understanding of the material can be increased and the activities and positive attitudes of students in learning activities also increase.

After trial II is completed, a Geogebra-assisted problembased learning tool is obtained as a final draft that meets valid, practical, and effective criteria which can then improve the ability to solve mathematical problems. Geogebra-assisted problem-based learning provides encouragement to students not only to think concretely, but more so to think of abstract and complex ideas. This learning was also tested on subjects who were already at the level of formal operational thinking where the subjects of this study were high school students of class XI who were over 12 years old. This is in accordance with Piaget's statement (Dahar, 2011: 136) in his theory of the level of intellectual development reveals that "for children over the age of 11 years are at the stage of formal operational level thinking, the main progress in children is not necessary to think with the help of concrete objects because children have the ability to think abstractly ".

Syahputra and Surya (2017: 84) in their research findings stated that "problem based learning models can be implemented to improve students' high-order thinking abilities in solving mathematical problems". So it can be concluded that students' mathematical problem solving abilities can be developed by applying the problem based learning model in learning.

\section{CONCLUSIONS}

The geogebra-assisted mathematics-based learning tool developed meets valid, practical and effective criteria and can improve the mathematical problem-solving ability of students of SMA Negeri 1 Kabanjahe..

\section{REFERENCES}

[1] Afgani, M.W, Darmawijoyo, Purwoko. 2008. Pengembangan Media Website Pembelajaran Materi Program Linear Untuk Siswa Sekolah Menengah Atas. Jurnal Pendidikan Matematika, Volume 2.No.2.

[2] Dahar, R,W. 2011. Teori - Teori Belajar Dan Pembelajaran . Jakarta : Erlangga

[3] Kusumah, Y.S, 2003. Desain dan Pengembangan Bahan Ajar Matematika Berbasiskan Teknologi Komputer. Journal Seminar Proceeding National Seminar on Science and Math Education.

[4] Nieveen, N. 1999. Prototyping to Reach Product Quality. In Jan Van den Akker, R.M. Branch, K. Gustafson, N. Nieveen \& Tj. Plomp (Eds). Design Approaches and Tools in Education and Training. Pp 125-135. Dordrecht: Kluwer Academic Publishers.

[5] Padmavathy, R. D. dan Mareesh, K. 2013. Effectiveness of Problem Based Learning in Mathematics. International Multidisciplinary eJournal. ISSN 2277-4262. Vol-II Issue-I. Pp 45-51.

[6] Rahmadani, R. 2015. Pengembangan Perangkat Pembelajaran Matematika Berorientasi pada Problem Based Learning untuk meningkatkan kemampuan pemecahan masalah metamatika siswa kls XI SMK YPK Medan. Tesis tidak diterbitkan. Medan : Program Pasca Sarjana UNIMED

[7] Rusman. 2011. Model-Model Pembelajaran Mengembangkan Profesionalisme Guru. Jakarta: Rajawali Pers.

[8] Sanjaya, Wina. 2006. Strategi Pembelajaran Berorientasi Standar Proses Pendidikan. Jakarta: Kencana

[9] Silver, H, E, Cindy. 2004. Problem-Based Learning :What and How Do Students Learn?. Plenum Publishing Corporation. Educational Psychology Review, vol 16.Abdurrahman, M. 2009. Pendidikan bagi Anak Berkesulitan Belajar. Jakarta: Rineka Cipta

[10] Subanindro. 2012. Pengembangan Perangkat Pembelajaran Trigonometri Berorientasikan Kemampuan Penalaran dan Komunikasi Matematik Siswa SMA. Yogyakarta: Prosiding Seminar Nasional Matematika dan Pendidikan Matematika FMIPA UNY.

[11] Syahputra, E. dan Surya, E. 2017. The Development of Learning Model Based on Problem Solving to Construct High-Order Thinking Skill on the Learning Mathematics of 11th Grade in SMA/MA. Journal of Education and Practice. ISSN 2222-1735 Vol.8 No.6. Pp 80-85. 
[12] Thiagarajan, S. Semmel, D.S. Semmel, M. (1974). Instructional Development for Training Teachers of Exceptional Children. A Sourse Book. Blomington: Central for Innovation on Teaching The Handicapped

[13] Tran, T, dkk. 2014. Discovery Learning with the Help of the GeoGebra Dynamic Geometry Software. International Journal of Learning, Teaching and Educational Research Vol. 7, No. 1, pp. 44-57, August 2014
[14] Trianto. 2011. Mendesain Model Pembelajaran Inovatif Progresif. Konsep Landasan, dan Implementasinya pada KTSP. Jakarta: Kencana Prenada Media Group.

[15] Walker, J.T. dan Lofton, S.P. 2003. Effect Of a Problem Based Learning Curriculum On Students' Perceptions of Self Directed Learning. Issues In Educational Research 13. University of Mississippi Medical Center

[16] Widyatiningtyas, Reviandari, dkk. 2015. The Impact of Problem-Based Learning Approach to Senior High School Students' Mathematics Critical Thinking Ability. IndoMS-JME, Volume 6, No. 2. July 2015. Pp. 30-38. 